\title{
Trdoleskov zapredkar (Yponomeuta cagnagella, Yponomeutidae, Lepidoptera) in sorodne vrste v Sloveniji
}

\author{
Maja JURC*
}

V Sloveniji v zadnjih letih pogosto na različnih grmovnih in drevesnih vrstah opažamo golobrste, ki jih povzročajo gosenice metuljev roda zapredkarjev (Yponomeuta). Neposreden razlog za prikaz prisotnih vrst omenjenega roda $v$ Sloveniji je letošnja namnožitev trdoleskovega zapredkarja. Prikazujemo domače vrste zapredkarjev roda Yponomeuta, poškodbe ki jih povzročajo, vzroke za namnožitve, naravne regulatorje in naravne dejavnike, ki zmanjšujejo velikosti njihovih populacij ter priporočene ukrepe za zmanjšanje populacij defoliatorjev.

\section{Določitev povzročiteljev poškodb na navadni tr- doleski}

Dne 10.5.2016 smo dobili obvestilo dr. Lene Marion, vodje oddelka za arboristiko podjetja Tisa d.o.o., Cesta v Prod 84, Ljubljana, da so na Poti spominov in tovarištva (tudi Poti ob žici) opazili gosenice na grmih. Listi grmov so bili skeletirani in prepredeni z zapredki (slika 6, 7). Poročajo tudi o obžiranju grmičkov trdoleske v Celju in na Bledu. Tudi naša opažanja obžiranja navadne trdoleske v bližini Naklega, Domžal, Kamnika, Kranja, Postojne in Ljubljane potrjujejo večjo velikost populacije povzročiteljev golobrsta. Analizirali smo poškodbe in nabrane gosenice na navadni trdoleski (Euonimus europaea L.) in ugotavili, da se na navadni trdoleski hranijo gosenice metulja - trdoleskovega zapredkarja Yponomeuta cagnagella (Hübner, 1813), Yponomeutidae, Lepidoptera).

Taksonomska uvrstitev trdoleskovega zapredkarja (Yponomeuta cagnagella)

Vrsto uvrščajo avtorji v novejšem času v družino Yponomeutidae (Reichholf-Riehm, 1991; Gershenson in Ulenberg, 1998; Ulenberg, 1999), po avtorjih iz starejšega obdobja pa $\mathrm{v}$ poddružino Hyponomeutinae (Escherich, 1931). Predstavnike družine Yponomeutidae so raziskovali že v 18. stoletju. Leta 1738 je entomolog Réaumur objavil risbe jajčnih legel, gosenic, bub in odraslih osebkov (adultov) še neopisanih metuljev zapredkarjev. Prvi opisi le-teh segajo v obdobje Linneja, ki je opisal nekaj vrst (Ulenberg, 1999). Rod Yponomeuta Latreille, 1796 je že pred pribl. 200 leti obsegal vrste Yponomeuta evonymella (Linnaeus, 1758) - čremsov zapredkar, Yponomeuta padella (Linnaeus, 1758) slivov zapredkar, Yponomeuta malinellus Zeller, 1838 jabolčni zapredkar, Yponomeuta cagnagella (Hübner, 1813) - trdoleskov zapredkar, Yponomeuta rorrella (Hübner, 1796) - vrbov zapredkar, Yponomeuta irrorella (Hübner, 1796), Yponomeuta plumbella (Denis \& Schiffermüller, 1775), Yponomeuta sedella Treitschke, 1832 - homuličin zapredkar. Vrste družine Yponomeutidae so razširjene po celem svetu, le v arktičnih predelih in puščavah jih ni. Poddružina Yponomeutinae obsega 231 vrst, med katerimi so številne z nejasnim taksonomskim položajem. Te vrste so razvrščene v 25 rodov (Gershenson in Ulenberg, 1998). V tej poddružini je več gospodarsko pomembnih vrst.

V Sloveniji so prisotne vrste : Y. cagnagella, $Y$. evonymella, Y. padella, Y. malinellus, Y. irrorella, $Y$. plumbella (Lesar in Govedič, 2010).

\section{O vrstah rodu Yponomeuta}

Metulje tega rodu z lahkoto prepoznamo. Vse vrste imajo podolgovata krila z rahlo zaokroženimi vrhovi, prednja krila so bela ali sivkasta s številnimi drobnimi črnimi pikami, zadnja krila so temnosivorjava. Večina vrst se med sabo loči po številu in razporeditvi pik na prednjih krilih in oprsju ter po intenziteti sive barve prednjih in zadnjih kril. $Y$. sedella ima prednja krila popolnoma siva in na terminalnem delu nima pik. Y. plumbella ima precej siva krila, razločevalen znak je ena večja črna packa $v$ bližini oprsja in druga na vrhu kril (slika 1).

Vrsti $Y$. rorrella in $Y$. irrorella imata precej siva prednja krila, sivina se stopnjuje od osnove proti vrhu kril, najintenzivnejša pa je v centru kril ter oblikuje temen terminalen obrobek. Naslednje tri vrste ( $Y$. padella, $Y$. malinellus, Yponomeuta mahalebella Guenée, 1845) nekateri taksonomi ne priznavajo kot samostojne vrste in jih obravnavajo kot $Y$. padella kompleks (zbirna vrsta). Metulji te skupine so spremenljivi v barvi, strukturno pa so si zelo podobni. Ločevanje posameznih vrst te skupine je pri odraslih osebkih nezanesljivo, vendar se jasno razlikujejo glede na gostiteljske rastline in oblike gosenic. Nekateri menijo, da se populacija te zbirne vrste deli na rase (forme), ki se v sedanjem času oblikujejo v vrste, - zato razlike med njimi še niso velike. Tako se gosenice $Y$. padella prehranjujejo v velikih skupinah v zapredkih na vrstah iz družine rožnic (Rosaceae) (preglednica 1). Y. malinellus ima podobno življenjsko okolje kot prej omenjena vrsta, prehranjuje pa se samo z listi jablane in hruške, Yponomeuta mahalebella Guenée, 1845 pa z listi rašeljike (preglednica 1). $Y$. cagnagella se pojavlja na navadni trdoleski in na gojeni sorodni vrsti Euonymus japonica Thunb. (preglednica 1). Navadna trdoleska je hrana tudi vrstama $Y$. irrorella in Y. plumbella (preglednica 1). Y. sedella se lahko prehranjuje tudi z navadno trdolesko, v Veliki Britaniji se značilno pojavlja na homulici (Sedum telephium L.) (preglednica 1). Y. rorrella je bila najdena na vrbah. Vrsta Y. evonymella (čremsov zapredkar) (slika 8, 9, 10, 11,12 ) se vedno pojavlja samo na čremsi (ReichholfRiehm, 1991), Živojinović (1970) pa navaja kot možne gostitelje še vrste rodu jerebik (Sorbus) ter navadno krhliko (Frangula alnus Mill.) (preglednica 1). 
Preglednica 1: Vrste rodu Yponomeuta, ki se pojavljajo v zahodni Evropi (nomenklatura prilagojena po Escherich, 1931; Živojinović, 1970; Povel, 1984; Torossian in Roques 1989; Menken in sod. 1992; Gershenson in Ulenberg, 1998; Fauna Europea) (Jurc, 1999, dopolnjeno)

\begin{tabular}{|c|c|c|}
\hline Vrsta rodu Yponomeuta & Gostitelj & Značilnosti vrste \\
\hline $\begin{array}{l}\text { slivov zapredkar } \\
\text { Yponomeuta padella } \\
\text { Sinonima: } \\
\text { = diffluellus Heinemann, } 1870 \\
\text { = rhamnellus Gershenson, } 1974\end{array}$ & $\begin{array}{l}\text { Rosaceae } \\
\text { - črn trn (Prunus spinosa L.) } \\
\text { - enovrati glog (Crataegus monogyna Jacq.) } \\
\text { - navadni glog (Crataegus laevigata /Poiret/ } \\
\text { DC.) } \\
\text { - sliva (Prunus domestica } \text { L.) } \\
\text { - češnja (Prunus avium L.) } \\
\text { - jerebika (Sorbus aucuparia } \text { L.) } \\
\text { - šmarna hrušica (Amelanchier ovalis Med.) } \\
\text { - nikoli čremsa (Prunus padus L.) }\end{array}$ & $\begin{array}{l}\text { - enoletna generacija } \\
\text { - } 5 \text { stadijev gosenic } \\
\text { - gosenice s črno glavo } \\
\text { - mlade gosenice ne grizejo listje tako kot } \\
\text { ostale vrste tega rodu, začnejo s skeletira- } \\
\text { njem od roba proti sredini lista } \\
\text { - zabubijo se v zapredkih in kokoni so pogo- } \\
\text { sto združeni v gručah }\end{array}$ \\
\hline $\begin{array}{l}\text { jabolčni zapredkar } \\
\text { Yponomeuta malinellus }\end{array}$ & $\begin{array}{l}\text { Rosaceae } \\
\text { - jablana (Malus domestica Borkh.) } \\
\text { - lesnika (Malus sylvestris Mill.) } \\
\text { - hruška (Pyrus communis L.) } \\
\text { - drobnica (Pyrus pyraster /L./ Burgst.) } \\
\text { - zimska hruška (Pyrus nivalis Jacqu.) }\end{array}$ & $\begin{array}{l}\text { - enoletna generacija } \\
\text { - } 5 \text { stadijev gosenic } \\
\text { - gosenice s črno glavo } \\
\text { - kokone oblikuje v urejenih vrstah na dnu } \\
\text { zapredka }\end{array}$ \\
\hline Yponomeuta mahalebella & $\begin{array}{l}\text { Rosaceae } \\
\text { - rašeljika (Prunus mahaleb L.) }\end{array}$ & $\begin{array}{l}\text { - enoletna generacija } \\
\text { - } 5 \text { stadijev gosenic } \\
\text { - gosenice s črno glavo }\end{array}$ \\
\hline $\begin{array}{l}\text { čremsov zapredkar } \\
\text { Yponomeuta evonymella } \\
\text { Sinonim: } \\
=\text { padi Zeller, } 1844\end{array}$ & $\begin{array}{l}\text { Rosaceae } \\
\text { - čremsa (Prunus padus L.) } \\
\text { - vrste rodu Sorbus } \\
\text { - Frangula alnus Mill. }\end{array}$ & $\begin{array}{l}\text { - enoletna generacija } \\
\text { - } 5 \text { stadijev gosenic } \\
\text { - gosenice s črno glavo } \\
\text { - zapredek bel, v kepah }\end{array}$ \\
\hline $\begin{array}{l}\text { vrbov zapredkar } \\
\text { Yponomeuta rorrella } \\
\text { Sinonim: } \\
\text { = gigas Rebel, } \mathbf{1 8 9 2 ?}\end{array}$ & 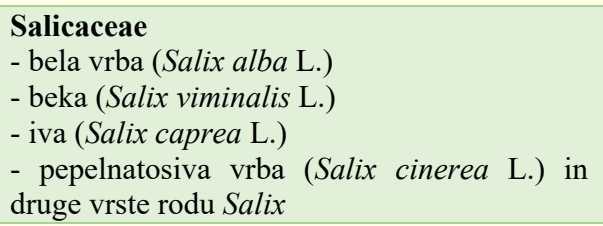 & $\begin{array}{l}\text { - enoletna generacija } \\
\text { - } 5 \text { stadijev gosenic } \\
\text { - gosenice s črno glavo }\end{array}$ \\
\hline Yponomeuta irrorella & $\begin{array}{l}\text { Celastraceae } \\
\text { - navadna trdoleska (Euonymus europaea) }\end{array}$ & $\begin{array}{l}\text { - enoletna generacija } \\
\text { - majhna rodnost (4-9 jajčec) } \\
\text { - } 5 \text { stadijev gosenic } \\
\text { - gosenice s črno glavo } \\
\text { - gosenice živijo posamično v zapredkih na } \\
\text { listih }\end{array}$ \\
\hline $\begin{array}{l}\text { trdoleskov zapredkar } \\
\text { Yponomeuta cagnagella } \\
\text { Sinonim: } \\
\text { = cognatella Hübner } \mathbf{1 8 2 5}\end{array}$ & $\begin{array}{l}\text { Celastraceae } \\
\text { - navadna trdoleska (Euonymus europaea) } \\
\text { Euonymus japonica }\end{array}$ & $\begin{array}{l}\text { - enoletna generacija } \\
\text { - } 5 \text { stadijev gosenic } \\
\text { - gosenice s črno glavo } \\
\text { - zapredek bel, v kepah, postane rahlo zle- } \\
\text { pljen } \\
\text { - gosenice oblikujejo kokone v urejenih vr- } \\
\text { stah }\end{array}$ \\
\hline Yponomeuta plumbella & $\begin{array}{l}\text { Celastraceae } \\
\text { - navadna trdoleska (Euonymus europaea) }\end{array}$ & $\begin{array}{l}\text { - enoletna generacija } \\
\text { - jajčeca odlaga posamično } \\
\text { - } 5 \text { stadijev gosenic } \\
\text { - gosenice s rjavorumeno glavo } \\
\text { - njune gosenice se ne prehranjujejo v skupi- } \\
\text { nah in bube se pojavljajo posamično. }\end{array}$ \\
\hline $\begin{array}{l}\text { homuličin zapredkar } \\
\text { Yponomeuta sedella } \\
\text { Sinonim: } \\
\text { =. vigintipunctata Retzius } \mathbf{1 7 8 3} \text {. }\end{array}$ & $\begin{array}{l}\text { Crassulaceae } \\
\text { - homulica (Sedum telephium L.) } \\
\text { Celastraceae } \\
\text { - navadna trdoleska (Euonymus europaea) }\end{array}$ & $\begin{array}{l}\text { - dvoletna generacija } \\
\text { - } 4 \text { stadiji gosenic } \\
\text { - gosenice s črno glavo }\end{array}$ \\
\hline
\end{tabular}

\section{Trdoleskov zapredkar Yponomeuta cagnagella}

Opis vrste: Majhen metulj; čez sprednja krila meri od 19 do $26 \mathrm{~mm}$, sprednja krila so pretežno bela, so resasto obrobljena in imajo štiri podolžne linije črnih pik (ki vključuje tudi linijo 4-7 pik proti spodnjemu robu). Odrasle gosenice so dolge $18-22 \mathrm{~mm}$, rumeno sive do zeleno sive, s črnimi pikami. Glava, predprsje in analni pokrovi so črni, mlade gosenice so temnejše (slika 2, 3, 4). Gosenice se levijo petkrat, odrasle se zabubijo v skupinah, v zapredkih v motno belih kokonih, ki so zlepljeni med sabo v gručah. Na lokaciji pri Kranju so letos pri nabiranju vzorcev gosenic 15. 5. 2016 že opazili zbiranje gosenic za zabubljenje (R. Pavlin) (slika 5). 
Habitat: Pojavlja se na robovih listnatih gozdov, na posamično rastočih grmih trdolesk. Najdemo ga $\mathrm{v}$ nižinskih listnatih gozdovih pa tudi drugje, kjer uspeva navadna trdoleska.

Razširjenost: Areal vrste je cela Evropa (Chinery, 1993). O najdbi vrste $Y$. cagnagella na Stajerskem in Koroškem poročata Lesar in Habeler (2005).

Pogostnost: Spreminja se od leta do leta, na splošno je vrsta nagnjena k namnožitvam.

Bionomija: Adulti se pojavijo junija in jih v naravi vidimo do oktobra. Adulti so zelo podobni adultom drugih vrst rodu Yponemeuta, lahko jih ločimo po resasto obrobljenih prednjih krilih in resice so popolnoma bele. Aktivni so ponoči. Y. cagnagella ima enoletno generacijo. Kopulirajo hitro po ekloziji. Samice odlagajo 2550 jajčec na gladko lubje mladih vej in na terminalne popke gostiteljskih rastlin od sredine junija do sredine julija. Jajčeca so ovalna, sploščena in prekrita z gumijastim izločkom iz zadka samic. Po treh do štirih tednih se izležejo gosenice $\left(\mathrm{L}_{1}\right)$, ki prezimijo v skupinah na mestu izvalitve, prekrite z ostanki jajčnih legel na gostiteljih. Gosenice postanejo aktivne zgodaj spomladi, kar sovpada $\mathrm{z}$ začetkom odganjanja gostiteljskih rastlin in mlado listje obžirajo od osnove proti vrhu. Lističe lahko poškodujejo tako, da le-ti rjavijo in odpadajo. Po desetih dneh so gosenice velike $5 \mathrm{~mm}$, rumenkaste s črnim ščitkom in črnimi oprsnimi nogami. Šele tedaj se začnejo zbirati v skupine na vejah in tam iz večjega števila listov oblikujejo zapredke (slika 2).

Zapredku dodajajo nove liste in tako povečujejo gnezdo. Ko so vsi listi v zapredku požrti, zapustijo gnezdo in oblikujejo novega. Junija se gosenice zabubijo v gručah. V njih so svilnati kokoni urejeni v vrstah in so obdani s svilenimi nitkami zapredka in z iztrebki gosenic.

Poškodbe: V listnatih gozdovih, logih in na rečnih obrežjih se na kamnitih pobočjih od nižin do montanskega pasu po vsej Sloveniji v toplih in sušnih letih pojavljajo golobrsti na navadni trdoleski (E. europaea). Tedaj so cele gostiteljske rastline prekrite z gnezdi trdoleskovega zapredkarja (slika 6, 7). Izbira gostiteljske rastline, ki rastejo na apnenčastih tleh.

\section{Čremsov zapredkar (Yponomeuta evonymella)}

Po nekaterih avtorjih se $Y$. evonymella pojavlja zgolj na čremsi (Prunus padus L.), vendar najdemo objave, ki omenjajo, da čremsovega zapredkarja najdemo redko tudi na drugih predstavnikih družine rožnic - Rosaceae (vrste roda jerebik - Sorbus ter na navadni krhliki Rhamnus frangula L.). Več v prispevku Jurc (1999) (slika 8, 9, 10, 11, 12).

\section{Vzroki za nastanek gradacij ter njihova naravna regulacija \\ Vremenski dejavniki}

Vremenski dejavniki, kot sta temperatura in vlažnost, imajo odločilni pomen pri pojavljanju gradacij zapredkarjev. Mile zime brez snega omogočajo uspešno preživetje gosenic v zapredkih. Za rojenje metuljev (to je zbiranje spolno zrelih osebkov kot rezultat izločanja feromonov samic, letanje samcev ter kopula) je potrebna temperatura nad $12{ }^{\circ} \mathrm{C}$ med 13. in 16 . uro popoldne. Aktivnost metuljev zelo naraste če je ta temperaturni prag presežen. Vroča in suha poletja ustrezajo samicam, ki takrat optimalno ležejo jajčeca. Obdobja dolgotrajnejšega deževja v času rojenja ovirajo letenje, prepoznavanje med partnerji ter hranjenje, kar pripelje do zakasnitve pri odlaganju jajčec. Take razmere povzročijo pri gosenicah pomanjkanje teka, občutljivost glede parazitov ter selitev na rastline, ki niso gostitelji posameznih vrst zapredkarjev. Tudi močnejši vetrovi - že s hitrostjo več kot $2 \mathrm{~m} / \mathrm{s}$, resno ovirajo let samcev.

Vpliv zajedavcev, plenilcev in bolezni na dinamiko populacij

Zapredkarji imajo v Evropi številne naravne sovražnike. Različne vrste imajo iste skupine škodljivih dejavnikov, ki pa se pojavljajo v različnem številu. Najpomembnejši in najučinkovitejši redukcijski dejavniki so različne vrste iz skupine os najezdnic (Ichneumonidae). Med njimi je Herpestomus brunnicornis (Gravenhorst, 1829), parazitoid larv in bub, zelo dobro prilagojen življenjskemu ciklu zapredkarjev. Leglico ima zelo kratko, vdira v kokone in lega jajca v bube. Diadegma armillatum (Gravenhorst, 1829) je parazitoid gosenic (Herard in Prevost, 1996), prav tako Itoplectis maculator (Fabricius, 1775), ki pa ima zelo širok spekter gostiteljev (Nierhaus-Wundervald, 1998). Muhe iz skupine muh goseničark (Tachinidae) so prav tako pomembni parazitoidi kasnejših stadijev gosenic. Številne vrste zemeljskih os (Chalcidoidea) pa so hiperparaziti pri zapredkarjih, kar pomeni, da zajedajo njihove naravne sovražnike. Predstavljajo učinkovit mehanizem, ki preprečuje, da bi se zajedalci zapredkarjev razmnožili v taki meri, da bi ogrozili zapredkarje. Zajedalec jajc Ageniaspis fuscicollis (Dalman, 1820) predstavlja izjemo tega pravila in zato je najuspešnejši reduktor populacije zapredkarjev. Ima izjemno razmnoževalno sposobnost - zaradi pojava poliembrionije se pri tej vrsti iz enega jajčeca razvije do 80 osebkov. Poleg tega je ta vrsta zelo selektivna pri izbiri svojega gostitelja in napada le zapredkarje.

Druga skupina pomembnih naravnih sovražnikov so plenilci (predatorji). Navadna strigalica (Forficula auricularia Linnaeus, 1758, Dermaptera) je plenilec jajc, prav tako larve navadne tenčičarice (Chrysoperla carnea (Stephens, 1836), Neuroptera: Chrysopidae). Drugi plenilci posegajo $\mathrm{v}$ populacijo zapredkarjev predvsem $\mathrm{v}$ fazi razvoja gosenic. V kolikor so sestoji gostiteljskih rastlin zelo presvetljeni in je vreme toplo so plenilci sposobni popolnoma uničiti praktično celotno populacijo zapredkarjev. Muha Agria mamillata (Pandelle, 1896) je pomembna plenilka in jo pogosto najdemo na zapredkih (Escherich, 1942). O pomenu ptičev pri kontroli zapredkarjev mnenja niso enotna.

Bolezni zapredkarjev povzročajo virusi, glive in ogorčice. Največkrat se ti dejavniki razširijo v populaciji v času najintenzivnejšega prehranjevanja, to je v petem larvalnem štadiju. Običajno povzročajo smrt gosenic v nekaj dneh. V kolikor okužijo gosenico virusi, se ta močno napihne. Ob najmanjšem dotiku se razpoči in razpršijo se zelo virulentne kapljice, polne virusov. Mrtve gosenice pogosto opazimo v velikih skupinah na zapredkih ali na listju. Take okužbe in množični pogini so predvsem pogosti v dolgih deževnih obdobjih ali v okoljih, kjer je velika zračna vlaga. Nemški raziskovalci (Purrini in Skatulla, 1977) poročajo o virusni bolezni - 
jedrni polihedrozi, ki je okužila vse stadije gosenic $Y$. padella (na Crataegus monogyna s.1.) in Y. evonymella (na Prunus padus in Salix sp.) v gozdovih v bližini Münchna. Omenjena virusna okužba je najpomembnejši povzročitelj mortalitete gosenic in predstavlja pomemben dejavnik prekinitve gradacije.

Lokalne namnožitve zapredkarjev se po določenem času končajo zaradi vpliva naravnih regulacijskih dejavnikov, kot so neugodne vremenske razmere, konkurenca med osebki iste vrste za hrano ali antagonisti. Naravni sovražniki ne morejo preprečiti gradacije, ker se v dovolj velikem številu razmnožijo prepozno. Pomembno pa skrajšajo čas gradacije, med gradacijami pa regulirajo število svojih gostiteljev (Jurc, 1999).

\section{Zaključki}

Trdoleskov zapredkar se pogosto pojavlja v namnožitvah, vendar škode niso velike zaradi zgodnjega golobrsta gostitelja, ki kmalu ponovno olista. Ponavljajoči se golobrsti pa vodijo zaradi zmanjševanja asimilacijske površine v izčrpavanje gostitelja, ki sčasoma začne izgubljati prirastek, slabše cveti in manj obrodi. Manj semena pomeni manj hrane za njegove primarne konzumente (ptice, sesalce). Povečanje živalske hrane v obliki enormnih količin gosenic pa vsekakor pozitivno vpliva na njihove konzumente in naprej na konzumente le-teh. Nazoren podatek je, da se na črnem trnu pojavlja v povprečju 488 gosenic vrste $Y$. padella na $\mathrm{m}^{2}$ površine listja (Munster-Swendsen, 1982).

Zatiranja trdoleskovega zapredkarja ne priporočamo, saj gradacije ustavljajo že same namnožitve parazitov, parazitoidov in predatorjev, ki sledijo namnožitvam zapredkarjev. Tudi mrzlo in deževno vreme deluje inhibitorno na vse metulje in ustavlja namnožitve. Kot uspešno in okolju neškodljivo sredstvo se je izkazal preparat na osnovi Bacillus thuringiensis (Mowat in Clawson, 1988). Potekajo tudi poskusi z uporabo atraktantov na osnovi feromonov za skupino zapredkarjev. Kemičnega zatiranja $v$ sestojih in urbanih področjih ne priporočamo.

\section{Zahvala}

Dr. Leni Marion se zahvaljujem za fotografije.

\section{Viri}

Chinery M. 1993. Insects of Britain \& Northern Europe. 3rd Edition, Harper Collins Publishers, 320

Escherich K. 1931. Die Forstinsekten Mitteleuropas. Lepidopteroidea: Die Schnabelhafte (Panorpatae); die Köcherfliegen (Trichoptera); die Schmetterlinge I (Lepidoptera I): Allgemeines, Kleinschmetterlinge, Spanner und Eulen. Dritter Band. Verlagsbuchhandlung Paul Parey, Berlin, 825
Escherich K. 1942. Die Forstinsekten Mitteleuropas. Hymenoptera (Hautflügler) und Diptera (Zweiflügler). V Band. Verlagsbuchhandlung Paul Parey, Berlin, 746 str.

Gershenson Z. S., Ulenberg S. A. 1998. The Yponomeutinae of the World exclusive of the Americas. Koninklijke Akademie van Wetenschappen, Verhandelingen afdeling Natuurkunde, Tweede Reeks, 99: 202

Gomboc S. 1994. Favnistični pregled gospodarsko pomembnih vrst metuljev (Lepidoptera) v Prekmurju. Diplomska naloga, Univerza v Ljubljani, Biotehniška fakulteta, Oddelek za agronomijo, 222 str., + Priloga k diplomski nalogi Favna metuljev (Lepidoptera) Prekmurja s podatki, 99

Jurc M. 1999. Biologija in naravna regulacija čremsovega zapredkarja (Yponomeuta evonymella L., Yponomeutidae, Microlepidoptera). Gozdarski vestnik, 57, 9: 394-399

Lesar T., Govedič M. 2010. Check list of Slovenian Microletidoptera. Natura Sloveniae, 12, 1: 35-125

Lesar T., Habeler H. 2005. Beitrag zur Kenntnis der Kleinschmetterlinge (Microlepidoptera) von Štajersko und Koroško in Slowenien. Natura Sloveniae 7, 2: 3-127

Fauna Europea http://www.fauna-eu.org/ Yponomeuta Latreille, 1796, Accessed 23.5.2016

Herard F., Prevost G. 1997. Suitability of Yponomeuta malinellus and Y. cagnagellus (Lepidoptera: Yponomeutidae) as hosts of Diadegma armillata (Hymenoptera: Ichneumonidae). Environmental Entomo$\operatorname{logy} 26$ (4): 933 - 938

Menken B. J., Herreout W. M., Wiebes J. T. 1992. Small Ermine Moths (Yponomeuta): Their Host Relations and Evolution. Ann. Rev. Entomol., 37: 41-66

Mowat D. J., Clawson S. 1988. Insecticide treatments for the control of small ermine moth, Yponomeuta padella (L.) in hawthorn hedges. Agriculture, Ecosystems and Environment, 21, 3-4: 245-253

Munster-Swendsen M. 1982. Outbreak of the small ermine moth, Yponomeuta padella (L.) (Lepidoptera: Yponomeutidae) at Rosnaes in 1981. Entomologiske-Meddelelser, 49, 2: 77-84

Nierhaus-Wunderwald D. 1998. Biologie et régulation naturelle des hyponomeutes. Notice pour le praticien. WSL/FNP Birmensdorf, 8

Povel G. D. E. 1984. The identification of the European small ermine moths, with special reference to the Yponomeuta padellus - complex (Lepidoptera, Yponomeutidae). Proc.K.Ned.Akad. Wet., Ser. C 87, 2: $149-180$

Purrini K., Skatulla U. 1977. A new virus disease of Yponomeuta (Hyponomeuta) padella and $Y$. (H.) evonymella. Anzeiger für Schadlingskunde Pflanzenschutz Umweltschutz. 50, 1: 12-13

Reichholf-Riehm H. 1991. Butterflies and moths of Britain and Europe. The Crowood Press, 287

Torossian C., Roques L. 1989. Cycle biologique et importance appliquée de 1 'éspéce Yponomeuta rorellus Hübner dans les ripisylves á Salix alba de la région Midi-Pyrénées. Acta Oecol., 10, 1: 47-63

Ulenberg S. A. 1999. Phylogeny of the Yponomeutidae/Lepidoptera/, Institute for Biodiversity and Ecosystem Dynamica / Zoological Museum Amsterdam, Department of Entomology, 2 s. (http: / / www zma. bio. una. Nl departments / entomol / Yponomeutidae. html) Živojinović S. 1970. Šumarska entomologija. Univerzitet u Beogradu. Zavod za izdavanje udžbenika SRS, Beograd, 472

Biotehniška fakulteta, Oddelek za gozdarstvo in obnovljive gozdne vire, Večna pot 83, 1000 Ljubljana, Slovenija

*maja.jurc@bf.uni-lj.si 


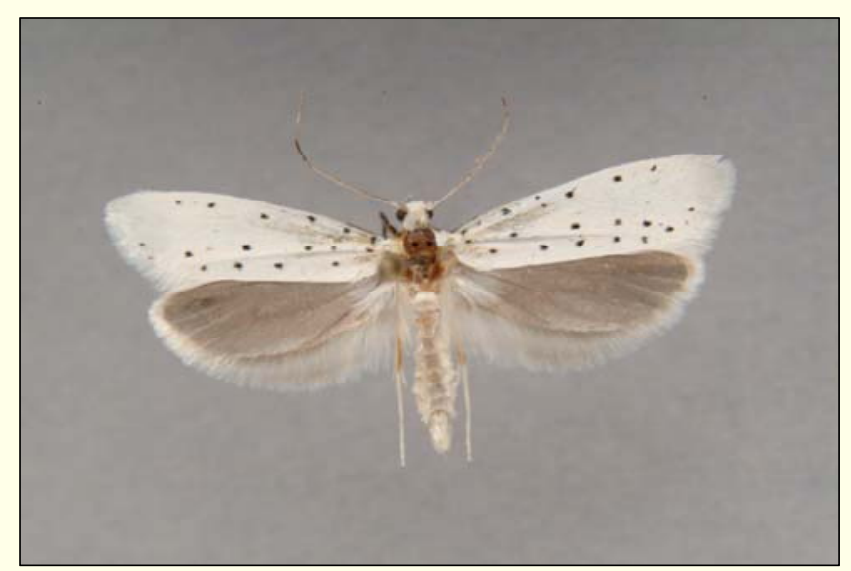

Slika 1: Yponomeuta sp. - imago (Foto: D. Jurc)

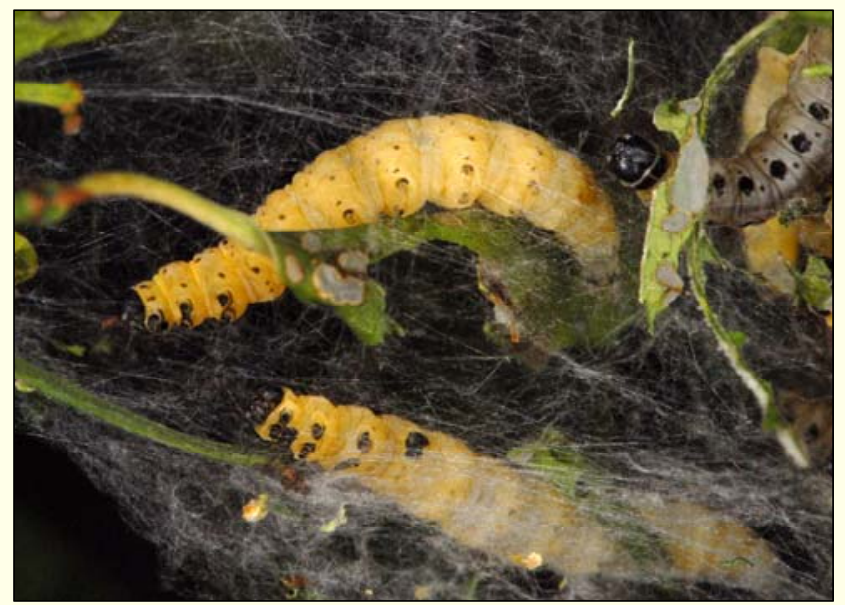

Slika 3: Gosenice v zapredku - glava, predprsje in analni pokrovi so črni, mlade gosenice so temnejše (Foto: D. Jurc)

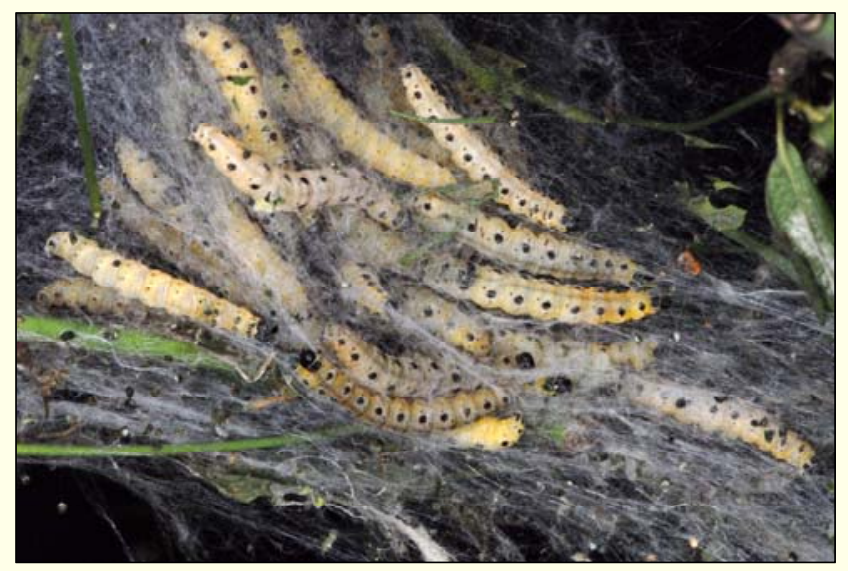

Slika 5: Gosenice se levijo petkrat, odrasle gosenice se zabubijo v skupinah, v zapredkih v motno belih kokonih, ki so zlepljeni med sabo v gručah (Foto: M. Jurc)

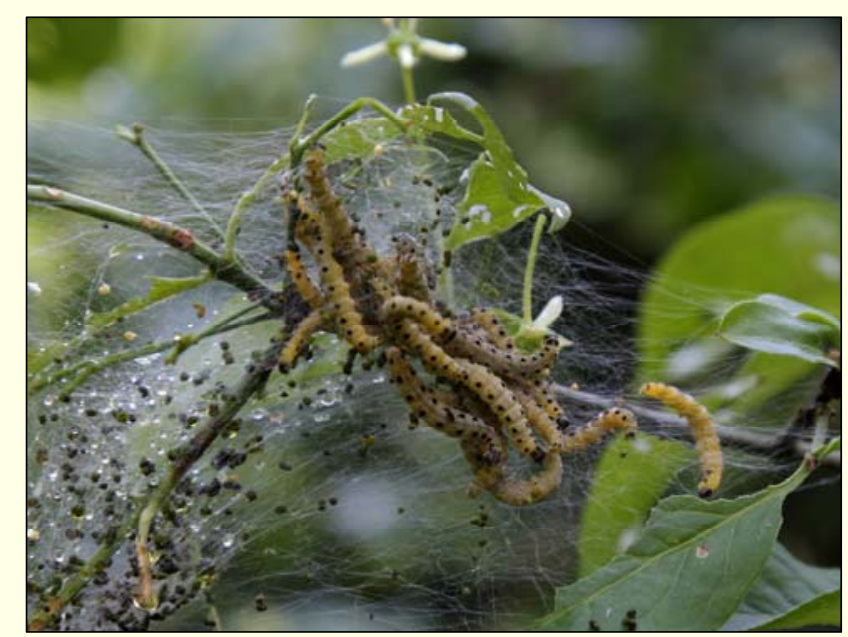

Slika 2: Gosenice Yponomeuta cagnagella, 17. 5. 2016, vrt Oddelka za gozdarstvo in obnovljive gozdne vire BF, (Foto: M. Jurc)

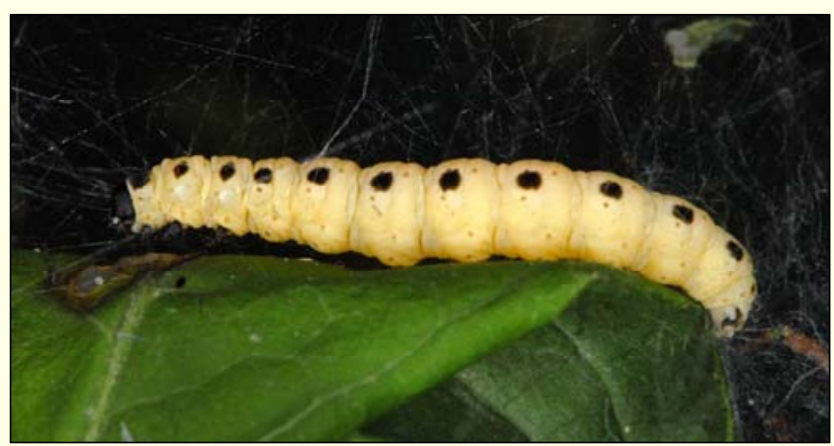

Slika 4: Odrasle gosenice so dolge 18-22 $\mathrm{mm}$, rumeno sive do zeleno sive, z črnimi pikami (Foto: D. Jurc)

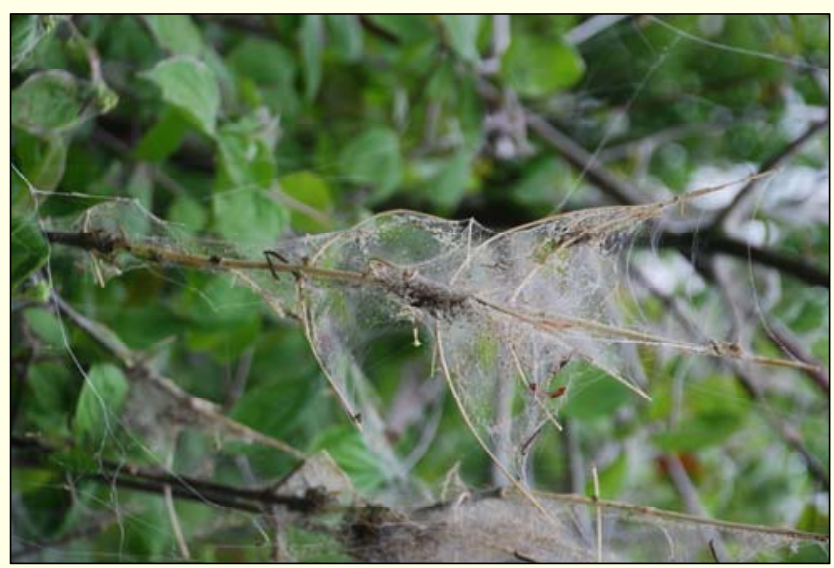

Slika 6: Defoliacije navadne trdoleske (Euonymus europaea L.), 10. 5. 2016, Ljubljana (Foto: L. Marion) 


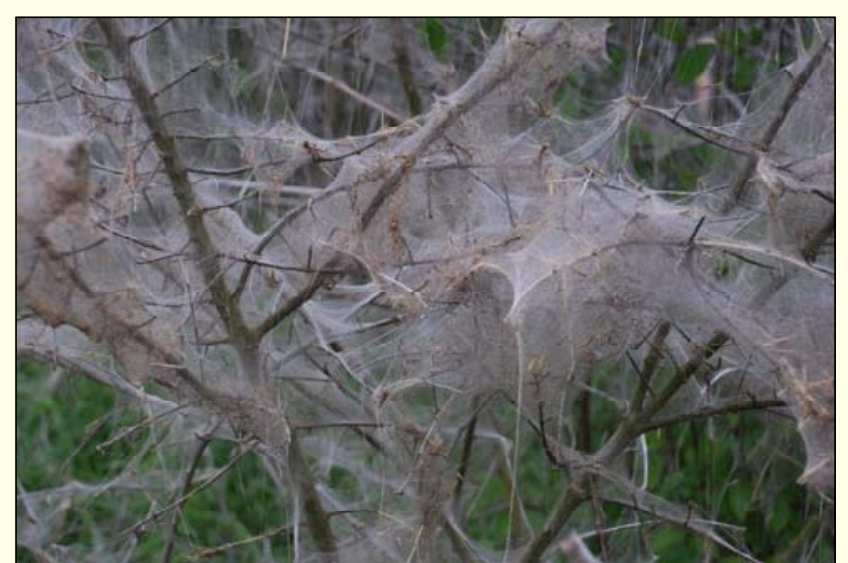

Slika 7: Močne defoliacije navadne trdoleske, 10. 5. 2016, Ljubljana (Foto: L. Marion)

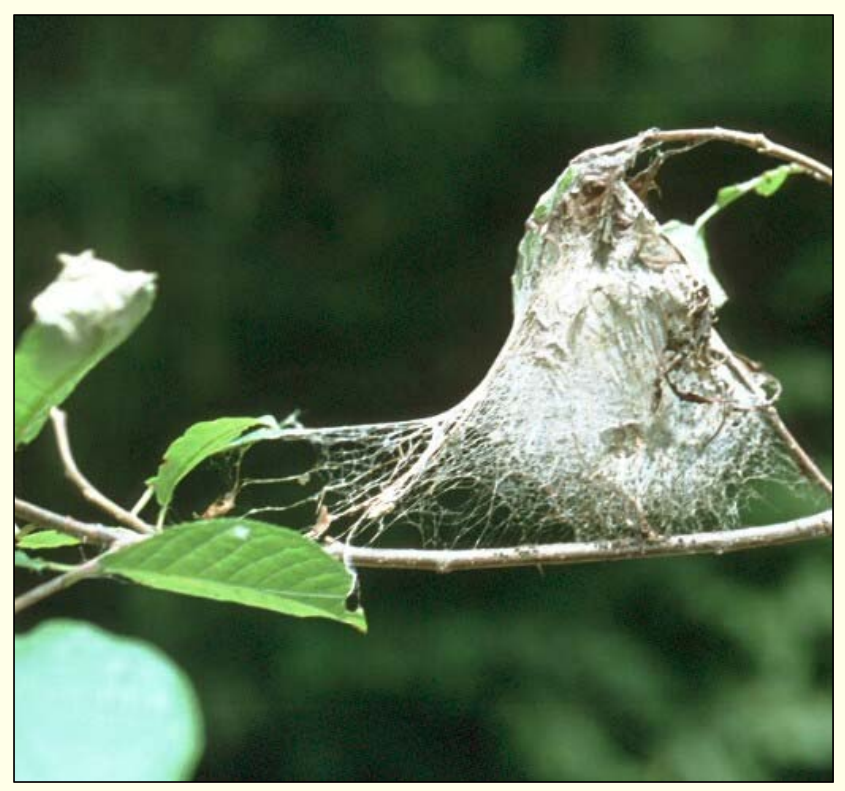

Slika 9: Zapredek Y. evonymella s kokoni na veji čremse (Prunus padus L.) (Foto: M. Jurc)

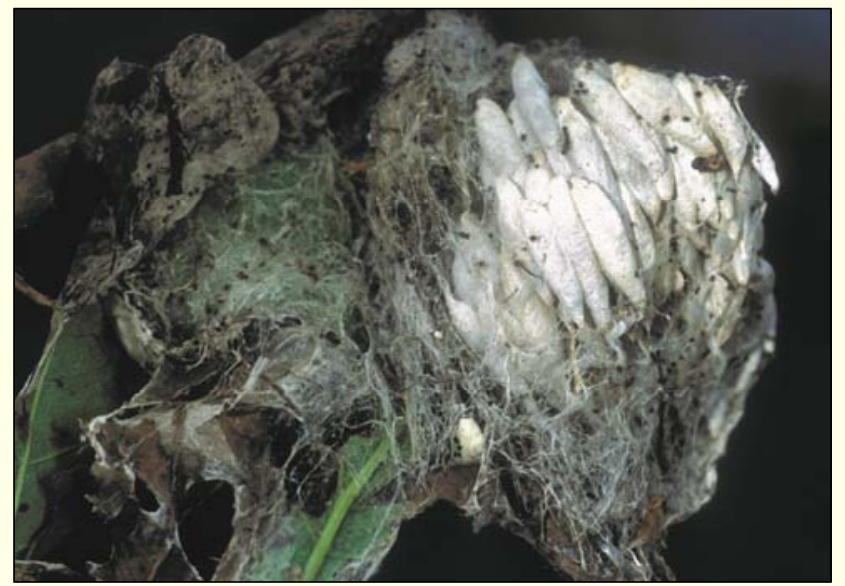

Slika 11: Zapredek z bubami Y. evonymella, revir Polana, 1999 (Foto: D. Jurc)

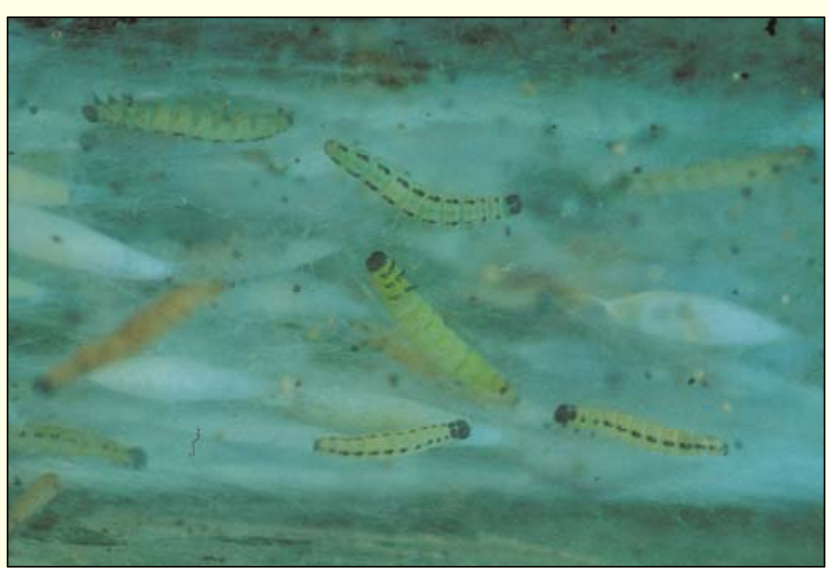

Slika 8: Gosenice čremsovega zapredkarja Yponomeuta evonymella, revir Polana, 1999 (Foto: D. Jurc)

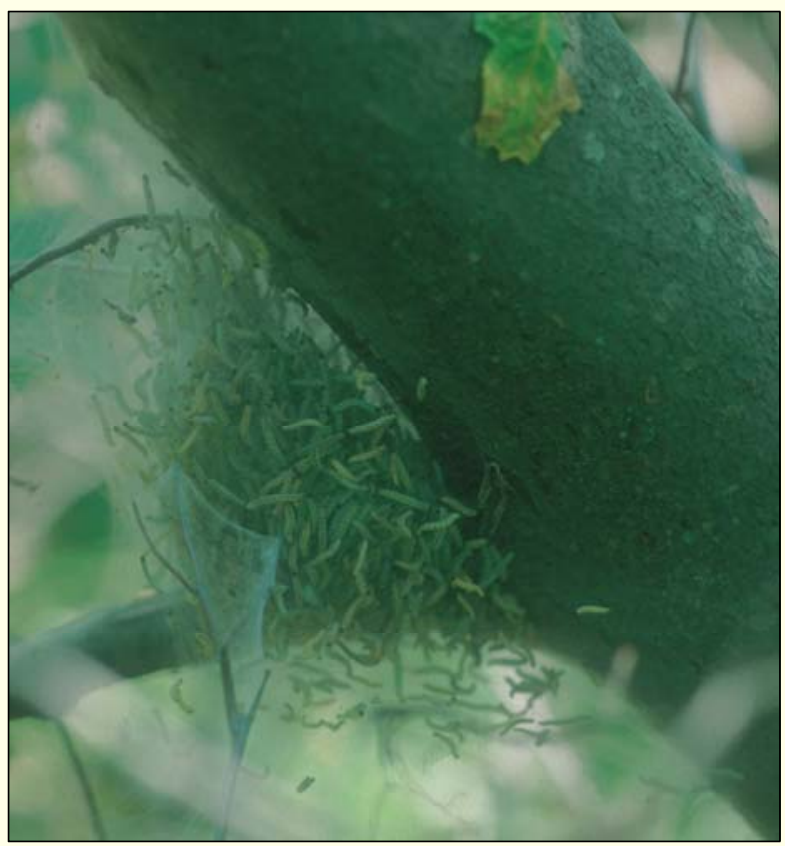

Slika 10: Zapredek z gosenicami $Y$. evonymella, celotno vidno polje je prepredeno $\mathrm{z}$ nitkami, tudi skorja čremse $(P$. padus L.), revir Polana, 1999 (Foto: D. Jurc)

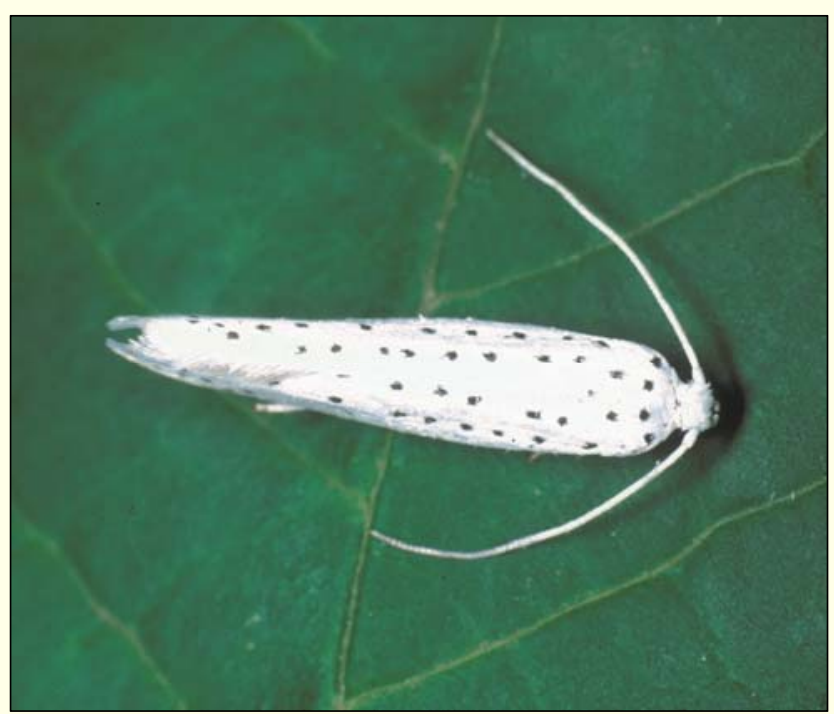

Slika 12: Čremsov zapredkar (Y. evonymella), metulj (Foto: D. Jurc) 